\title{
Adi Ortaklıklarda Sözleşmede Hüküm Bulunmaması Durumunda Haklı Sebeple Çıkarma Yapılıp Yapılamayacağı Meselesi
}

Av. Dr. Sarp ŞAHANKAYA*

Makalenin Geliş Tarihi: 29.03.2021 Kabul Tarihi: 11.06.2021

Bu makale hakem incelemesinden geçmiştir ve TÜBİTAK - ULAKBİM Veri Tabanında indekslenmektedir.

DOI $10.30915 / \mathrm{abd} .978852$

* Avukat,Ankara Barosu. https://orcid.org/0000-0002-3906-6977 


\section{ADI ORTAKLIKLARDA SÖZLEŞMEDE HÜKÜM BULUNMAMASI DURUMUNDA HAKLI SEBEPLE ÇIKARMA YAPILIP YAPILAMAYACAĞI MESELESI}

\section{öz}

Adi ortaklıklarda bir ortağın çıkarılması, çıkma ile birlikte Türk Borçlar Kanunu'nun 633.maddesinde ele alınmıştır. İsviçre Borçlar Kanunu 'nda adi ortaklıklarda ortağın çıkması ve çıkarılması kuramlarına yer verilmemiştir. Türk Borçlar Kanunu 'nun bu hükmü Alman Medeni Kanunu’nun çıkmaya ilişkin 736.maddesi ve ortağı çıkarmaya ilişkin 737.maddesinin tek madde olarak birleştirilmiş halidir. Buna karşılık; mehaz Alman Medeni Kanunu'nda yer verilen tek çıkarma sebebi olan "bir ortak şahsında haklı sebep gerçekleşmesine” TBK m. 633'te yer verilmemiştir. Diğer yandan; Alman Medeni Kanunu'nda bizden farklı olarak haklı sebeple fesih mahkeme kararı ile yapılmamaktadır ve bu hususun da yapılacak değerlendirmede göz önünde tutulması gerekmektedir. Bu çalışmada bir ortak özelinde haklı sebep gerçekleştiğinde çıkarma yapılıp yapılmayacağı ve hangi usulün benimsenmesi gerektiği üzerinde durulacaktır.

\section{Anahtar Kelimeler:}

Adi Ortaklık

Türk Borçlar Kanunu 633. madde
Haklı Sebep

Haklı Sebeple Fesih 


\title{
THE ISSUE OF EXCLUSION OF A PARTNER WITH JUST CAUSES IN ABSENCE OF CONTRACTUAL AGREEMENT AT ORDINARY PARTNERSHIPS
}

\begin{abstract}
The exclusion of a partner -with withdrawal of a partner - in ordinary partnerships are discussed in Turkish Code of Obligations Article 633. Swiss Code of Obligations do not involve a provision about withdrawal and exclusion of a partner in ordinary partnerships. This provision of Turkish Code of Obligations is unified version of German Civil Code Article 736 - which concerns withdrawal - and Article 737, which concerns exclusion of a partner. Correspondingly; the only exclusion reason determined in source German Civil Code article which is "occuring of a partner related just cause " is not featured in Turkish Code of Obligations Article 633. Additionally; -differently from our provisions-termination of ordinary partnership with just causes does not take effect with a court decision in German Civil Code and this fact must be considered in this discussion. In this article we analyze if it is possible to exclude a partner when partner related just cause happens and which method should be accepted.
\end{abstract}

\section{Keywords:}

Ordinary Partnership

Exclusion

Just Cause

Turkish Code of Obligations Article 633

Termination with Just Cause 
Adi Ortaklıklarda Sözleşmede Hüküm Bulunmaması Durumunda

Hakı Sebeple Çıkarma Yapılıp Yapılamayacağı Meselesi

\section{GíRiş}

Bu çalışmada; hukukumuzda adi ortaklıklarda, ortağın şahsında haklı sebep gerçekleştiğinde ve sözleşmede Türk Borçlar Kanunu’nun (TBK) 633. maddesinde belirtilen devam hükmü bulunmadığında çıkarma yapılıp yapılamayacağı incelenecektir.

TBK m. 633; "Bir ortağın fesih bildiriminde bulunması, kısıtlanmasi, iflast, tasfiyedeki payının cebrî icra yoluyla paraya çevrilmesi veya ölmesi hâlinde, sözleşmede ortaklı̆̆ın diğer ortaklarla devam edeceğine ilişkin bir hüküm varsa, bu durumlardan biri gerçekleştiğinde, o ortak veya temsilcisi ya da ölen ortağın mirasçısı ortaklıktan çıkabilir veya diğer ortaklar tarafindan yazıl olarak yapılacak bir bildirimle ortaklıktan çıkarılabilir" ifadelerini haizdir.

TBK m. 633 hükmü; Alman Medeni Kanunu’nun (BGB) 736. ve 737. maddelerinden alınmıştır (TBK m. 633 gerekçesi). BGB $\$ 736$, adi ortaklıktan çıkmaya ilişkindir ve bu hükümde çıkma sebepleri bir ortağın fesih bildiriminde bulunması, ölümü veya iflas etmesi şeklinde sayılmıştır. BGB $\$ 737$ ise kalan ortakların, şahsında haklı sebep gerçekleşen ortağ masını ele almaktadır. Türk Borçlar Kanunu’nun 633.maddesinde haklı sebep yaratan ortağın adi ortaklıktan çıkarılması hakkında bir ifadeye yer verilmemektedir. TBK ile mehaz BGB $\$ 736$ ve 737 ’nin tek hüküm olarak birleştirilmesi amaçlanmış, BGB $\$ 737$ 'deki yegane çıkarma sebebine - bir ortak şahsında haklı sebep doğması - TBK m. 633'te yer verilmemiştir. Haklı sebep yaratan ortağın çıkarılmasına yer verilmemesi "unutma" sonucu, bilinçli olmayan bir tercih olarak nitelenmiştir. ${ }^{[1]} \mathrm{TBK}$ m. 633 hükmünün, BGB $\$ 737 ’$ nin temel felsefesini yansıtmadığı yönünde de eleştiri yapilmaktadır. ${ }^{[2]}$

[1] KARAHAN, S./AKIN, M.Y. (2013). Şirketler Hukuku. (2.Baskı). Konya. Mimoza Yayınlan, $s .83$ ve aynı sayfadaki 2 numaralı atıf.

HIZIR; haklı sebeple fesih istemi ile mahkemeye başvuran ortağın çıkarılması konusunda dayanak olmadığını belirtmektedir. (HIZIR, S. (2011). "6098 Sayılı (Yeni) Borçlar Kanunu’nun 633'üncü Maddesine Göre Adi Şirketten Çıkmanın ve Çıkarılmanın Genel Şartları ve Usulü”. Sarper Süzek'e Armağan. İstanbul. Beta Yayınları, s.2837.) Yazar; 633.maddede zikredilenler dışındaki sebeplerin ancak sözleşmede açıkça belirtilmesi durumunda çıkarmaya vesile olabileceğini de belirtmektedir (s.2831).

[2] TÜRKMEN, E. (2018). "Adi Ortaklıkta Haklı Sebeple Çıkarma Bă̆lamında TBK 633 Hükmüne Eleştirel Bir Bakı̧̧”. Terazi Hukuk Dergisi Cilt:13 Sayı:148. Ankara. Seçkin Yayınları, s.91. 
Adi ortaklıktan çıkma-çıkarma hükümlerinin BGB'den alınması; adi ortaklığa ilişkin kalan hükümlerin - özellikle haklı sebeple fesih hükmünün- ise İsviçre Borçlar Kanunu'ndan (OR) alınması da karışıklığa sebebiyet vermektedir. TBK'nin adi ortaklık konusunda farklı ülke kanunlarını karma şekilde mehaz alma tercihi, Alman ve İsviçre hukuklarının çıkmaçıkarma konusundaki ayrı ve farklı anlayışları nedeniyle sorun yaratmaktadır. İki ülkenin mevzuatı ve kanun sistematikleri birbirinden farklıdır. İki ülkenin hukuku da kendi kanun düzenlerinde, birbirini tamamlayan ve kendi içerisinde çelişmeyen bir sistem ortaya koyabilmektedir. TBK ise bu konuda bir nevi iki farklı kanun sistemini birleştirmeye çalıştığ 1 için net ve birbiri ile uyumlu bir düzen ortaya koyamamaktadır.

\section{1- Adi Ortaklıklarda Haklı Sebeple Çıkarma Konusunda Kanun Boşluğu Olup Olmadığının Tespiti}

İlk aşamada; haklı sebeple çıkarma ${ }^{[3]}$ konusunda hüküm bulunmaması üzerinde durulmalıdır. Bu konu doktrinimizde de ele alınmıştır. ÇELIK$B O Y A$, haklı sebebe yol açan ortağın çıkartılması konusunda bir hukuk boşluğu bulunduğunu belirtmektedir ve Kanunumuzda haklı sebeple fesih ve ortaklıktan çıkarma kurumları ayrı ayrı bulunurken haklı sebebe yol açan ortağın çıkarılmasını engelleyen bir yorum yapılmaması gerektiğini ileri sürmektedir. Bu noktada TMK m. 1 uyarınca hukukî boşluğun hâkim tarafından doldurulacağı ve kıyas yapılırken TTK m. 255 değil doğrudan adi ortaklık için sevkedilmiş TBK m. 633'ün haklı sebep oluşturan ortağa karşı uygulanması gerektiğini belirtmektedir. ${ }^{[4]}$ ÇELIKK, bu konuda 818 sayılı eski Borçlar Kanunu (BK) döneminde kanun boşluğu bulunduğu ve kollektif şirketlere ait hükümlerin uygulanması gerektiği yönündeki görüşü belirterek; TBK döneminde sözleşmede hüküm bulunmayan durumlarda haklı sebeple ortaklıktan çıkarma kurumunun işletilmesinin güçleştiğini çünkü artık kanun boşluğu bulunmadığını ileri sürmektedir. ${ }^{[5]} B A D A K$

[3] Haklı sebeple çıkarma; bir ortağı rızası olmaksızın ortaklıktan ayırmak anlamına gelmektedir. Kanunda belirtilen çıkarma sebepleri, ortaklığın devamını tehlikeye düşüren hallerdir. (ÇAMOĞLU, E. (1976). Kollektif Ortaklıkta Haklı Sebep Kavramı ve Ortağın Haklı Sebeple Çıkarılması. İstanbul. Fakülteler Matbaası, s.125.)

[4] ÇELIKKBOYA, K. (2015). "Adi Ortaklıktan Çıkma ve Çıkarmanın Koşulları". Galatasaray Üniversitesi Hukuk Fakültesi Dergisi. Sayı:2015/2. İstanbul. Beta Yayınları, s.221.

ÇELIKKBOYA'nın açıklamalarından adi ortaklıklarda bir ortağın haklı sebeple çıkarılması için ortaklık sözleşmesinde hüküm bulunması ve ortakların karar alması gerektiğini anlıyoruz.

[5] ÇELİK, A. (2017). Anonim Şirketlerde Ortaklıktan Çıkarılma. (4.Baskı). Ankara. 
$A Y B A R$ da benzer yönde; sözleşmede hüküm bulunmayan durumlarda haklı sebeple çıkarma yapılamayacağını ve kollektif şirket hükümlerinin kıyasen uygulanamayacağını çünkü TBK'nin ortaklıktan çıkarma kurumunu düzenlemesi nedeniyle artık bir kanun boşluğu bulunmadığını ileri sürmektedir. ${ }^{[6]}$ KARAYALÇIN, BK döneminde, kollektif şirket hükümlerinin kıyasen uygulanmasından ziyade haklı sebeple feshe nazaran daha hafif yaptırım olan ortaklıktan çıkarmanın mahkemeden talep edilebileceğini dile getirmiştir. ${ }^{[7]} K A R A H A N / A K I N$ ise adi ortaklıkta haklı sebeple çıkarma konusunda boşluk bulunduğunu belirterek, kanun koyucunun diğer şirket türleri açısından tanıdığı bu imkânı adi ortaklıklarda tanımamasının mantıklı olmadığına vurgu yaparak TTK m. 255 hükmünün kıyasen uygulanarak boşluğun doldurulabileceğini ileri sürmektedir. ${ }^{[8]}$

Kanun boşluğu; kanunun lafzından bir konunun çözümü için hüküm çıkmaması ve yapılan yorum ile eylem, davranış veya ilişkinin çözümlenememesidir. Başka bir deyişle; bu durumda yapılması gereken kanunî düzenlemenin yapılmamış olması söz konusudur. ${ }^{[9]}$ Kanunda gerçekten boşluk olup olmadığının belirlenebilmesi için kanunun bütün olarak yorumlanması gerekir. Hâkim, kanunun bu konuyu düzenlemekten bilinçli olarak imtina ettiği kanaatinde olursa kanun boşluğu olmadığı sonucuna varacaktır. ${ }^{[10]}$ Adi ortaklıklarda haklı sebeple çıkarma konusunda boşluk

Seçkin Yayınları, s.72.

Eski Kanun döneminde kanun boşluğu bulunduğu yönünde başka bir tespit için; AKKANAT, H. (2004). "Adi Ortaklıkta Haklı Sebeple İhraç Mümkün müdür?", İÜHFM, C. LXII, S.1-2, İstanbul, s.336 vd.

[6] BADAK AYBAR, Z. (2013). "6098 sayılı Türk Borçlar Kanunu’na Göre Adi Ortaklık Sözleşmesindeki Yenilikler ve Değişiklikler”. İstanbul Ticaret Üniverstesi Sosyal Bilimler Dergisi. Yıl:12 Sayı:24 Güz 2013/2. İstanbul, s.140.

[7] KARAYALÇIN, s.152-153

[8] KARAHAN/AKIN, s.83.

[9] FORTMOSER, P./VOGT. H. (2008). Einführung in das Recht. (4. Auflage). Bern. Stampfli Verlag, s.406 vd.; AKTAŞ, S. (2010). "Pozitif Hukukta Boşluk Kavramı". Erzincan Üniversitesi Hukuk Fakültesi Dergisi C. XIV, S. 1-2. Erzincan, s.16 (http://hukukdergi.erzincan.edu.tr/wp-content/uploads/2015/10/2010-XIV 1-1. pdf. Erişim Tarihi: 20.07.2020); BERGER, B. (2018). Allegemeines Schuldrecht. (3. Auflage). Bern. Stampfli Verlag, s.35 vd.; EDİS, S. (1993). Medenî Hukuka Giriş ve Başlangıç Hükümleri. (4.Baskı). Ankara. Dokuz Eylül Üniverstesi Hukuk Fakültesi Yayınları, s.121.

[10] FORTMOSER/VOGT, s.407-408.

Kanun boşluğu hüküm bulunmamasından veya hükmün somut olaya uygulanmasının belirsiz, açık olmayan sonuç vermesinden kaynaklanmaktadır. İlki praeter 
olup olmadığı konusunda ilk olarak düşünülmesi gereken adi ortaklıklarda haklı sebepler vuku bulduğunda ortaklıktan çıkarmaya nazaran daha sert bir yaptırım olan feshin zaten Kanunla tanındığı olmalıdır. Ayrıca mevzuatımızda başta kollektif şirketler olmak üzere diğer ortaklık türleri için haklı sebeple ortağın çıkarılması kurumu düzenlenmiştir. Kollektif şirketlerde bir ortağın haklı sebeple çıkarılmasını ele alan TTK m. 255'in gerekçesinde de açık şekilde; ortaklıktan çıkarmanın şahıs şirketi olmanın doğasından kaynaklanan bir kurum olduğu ifade edilmektedir ${ }^{[11]}$. Bu gerekçe adi ortaklıklar açısından doğrudan geçerli olabilecektir. Mehaz Alman hukuku mevzuat olarak (BGB $\$ 737$ ); İsviçre hukuku ise doktrinde dile getirilen görüşler nazara alındığında adi ortaklıklarda haklı sebeple ortağın çıkarılması için elverişlidir (aşağıda İsviçre doktrini ve uygulamasına ilişkin açıklamalara detaylı şekilde yer verilecektir). Genel hukukî bakış açısı bu şekilde iken kanun koyucumuzun adi ortaklıklarda haklı sebeple ortaklıktan çıkarma yapılmasına karşı olduğunu düşünmek mantıklı değildir. Adi ortaklıklarda haklı sebeple ortağın çıkarılmasının açık şekilde düzenlenmemiş olması kanun koyucunun bu imkânı bilinçli olarak vermek istemediğini göstermemektedir. TBK'de adi ortaklıktan çıkarma kurumunun haklı sebepler zikredilmeksizin farklı sebepler belirtilerek düzenlenmiş olması çıkarmanın haklı sebeple yapılması konusunda boşluk bulunduğu anlamına gelmektedir.

Adi ortaklıklarda haklı sebeple çıkarma konusunda mevzuatımızda kanun boşluğu bulunduğu tespitini yaptıktan sonra ikinci aşamada bu boşluğun nasıl doldurulacağı üzerine yoğunlaşmak gerekir. Kanun boşluğu söz konusu olduğunda TMK m. 1 yol göstermektedir. Hâkim, bir konu hakkında kanunda ve örf ve adet kurallarında hüküm bulunmayan du-

legem boşluk; ikincisi ise intra legem boşluk olarak anılmaktadır (FORTMOSER/ VOGT, s.420-421).

[11] TTK m. 255/I Gerekçe; “6762 saynlı Kanunun 197 nci maddesinin birinci fikrasinda "mukavelede hüküm bulunduğu takdirde" ibaresi iki şekilde yorumlanmaya müsaittir. Bir yoruma göre, şirket sözleşmesinde büküm bulunduğu takdirde, diğer ortaklar, kişiliğinde haklı sebep doğan ortağı bir kararla şirketten çıkarabilir. İkinci yorum uyarınca, diğer ortakların şahsında haklı sebep doğan ortağı şirketten çıkarma hakkı doğaldır. Bu yetkinin doğallığı kollektif şsirketin şahıs şirketi niteliğinden kaynaklanır. Onun için, söz konusu hakkın şirket sözleşmesinde bulunmast şart değildir. Şirket sözleşmesinde böyle bir düzenleme bulunmasa bile şirket mezkûr ortağı şirketten çıkarabilir. Düzenleme çıkarma kararının hangi nisapla alınması gerektiği hususunda yapılabilir. Karar, kural olarak oybirliği ile alınmalıdır; ancak şirket sözleşmesinde hüküm varsa çoğunlukla da alınabilir. Yargitay, haklı olarak ikinci yorumu benimsemiştir. Tasar, birinci fikrayı bu yoruma uygun olarak düzenlemiştir." 
rumlarda hukuk yaratmak ile mükelleftir. Hâkim kural koyarken benzer kanun hükümlerinden kyyas yolu ile istifade edebilir. ${ }^{[12]}$ Buna uygun olarak doktrinimizde; TBK m. 633'de zikredilmeyen haklı sebeple çıkarma konusunun TTK m. 255 hükmünün kıyasen uygulanması ile çözüme kavuşturulabileceği öne sürülmektedir. ${ }^{[13]}$ DOMANİÇ bu konuya ilişkin; haklı sebeple çıkarma yapılmasının evleviyet gereği mümkün olduğunu ileri sürmektedir. ${ }^{[14]}$ KARAYALÇIN da; ortağın şahsına ait sebeplerden dolayı ortaklığın feshi yerine ondan daha hafif ve ortaklık menfaatine uygun olan çıkarma yaptırımının uygulanabileceğini belirtmektedir. Yazar, mahkemenin TMK m. 1 hükmünü uygulayarak bu sonuca varabileceğini ileri sürmektedir. ${ }^{[15]}$ TÜRKMEN, kanun koyucunun ihmalinden kaynaklanan bir kanun boşluğu bulunduğunu belirterek şahsında haklı sebep gerçekleşen ortağın çıkarılması ve ortaklığın fesih/tasfiyeden korunması noktasında fırsatın kaçırıldığını öne sürmektedir. Ayrıca haklı sebeple fesih imkânı kanun tarafından tanınmış iken haklı sebeple çıkarmanın esirgenmemesi gerektiğini belirterek TTK m. 255 hükmünün kıyasen uygulanması gerektiği sonucuna varmaktadır. ${ }^{[16]}$

[12] BİLGE, N. (2019). Hukuk Başlangıcı Hukukun Temel Kavram ve Kurumlan. (36. Baskı). Ankara. Turhan Kitabevi, s.216-217; GÖZLER, K. (2020). Hukuka Giriş. (17.Baskı). Bursa. Ekin Basın Yayın Dağıtım, s.400 vd.; FORTMOSER/VOGT, s.409.

Hâkimin kanun boşluğunu doldurması, kanun maddesinin yorumlanması sonuç vermediğinde devreye girmektedir.

[13] ŞENER, O.H. (2019). Teorik ve Uygulamalı Ortaklıklar Hukuku Ders Kitabı. (4.Baskı). Ankara. Seçkin Yayıncılık, s.70-71; KARAHAN/AKIN, s.83.

ŞENER, ortaklık sözleşmesinde yer almasa dahi başka (haklı) sebeplerle çıkarma yapılmasını tartışmıştır. Bu açıklamalarında konkordato durumunu örnek vererek haklı sebeple feshin istenebileceğini ancak TTK m. 255 hükmünün kıyasen uygulanması ile bu durumda ortağın çıkarılmasının da olanaklı olması gerektiğini savunmuştur. Açıklamalarının devamında ise bu durumda dahi ortaklık sözleşmesinde ortaklığın diğer ortaklarla devam edeceğine ilişkin bir düzenlemenin varlığına ihtiyaç duyulduğunu belirtmiştir (ŞENER, s.69-70).

[14] DOMANİÇ, H. (1968). Adi, Kollektif ve Komandit Şirketler. (2.Baskı). İstanbul. Fakülteler Matbaası, s.44.

[15] KARAYALÇIN, Y. (1972). Ticaret Hukuku II. Şirketler Hukuku. (2.Baskı). Ankara. Sevinç Matbaası, s. 152-153.

Kanunda bu imkân açık şekilde tanınmasa da aksi yönde yani hâkim kararı ile ortaklıktan çıkarma yapılamayacağı yönünde de hüküm bulunmadığı gerekçesiyle de bu görüş savunulmaktadır (AKYAZAN, S. (1979). Kollektif, Komandit ve Adi Ortaklıklardan Oluşan Şahıs Şirketlerinde, Ortaklığın Fesih ve İnfisahı ve Ortaklıktan Çıkarma. Ankara Barosu Dergisi Yı1:1979 Sayı:5. Ankara, s.20).

[16] TÜRKMEN, s.90 vd. 


\section{2- Kıyasen Uygulanabileceği İleri Sürülen TTK m. 255 Hükmünün İncelenmesi ve Uygunluğu}

Doktrinimizde adi ortaklıklarda haklı sebeple çıkarma yapılması açısından kıyasen uygulanabileceği ileri sürülen TTK m. 255 hükmü için bu aşamada bir parantez açmak ve hükmü mercek altına almak gerekir. Hükmün ilk fikrası; "Bir ortağın kendisinden kaynaklanan sebeplerden dolayl şirketin feshinin istenebileceği durumlarda, diğer ortakların tümü o ortağgn şirketten çıkarılmasına ve şirketin devamına karar verebilir." şeklindedir. Bu hükme göre; kollektif şirketlerde ortaklıktan çıkarma, sözleşmede hüküm bulunmasa dahi kalan ortakların kararı ile yapılabilmektedir. TBK m. 633 ise ortakların kararı ile çıkarma yapılabilmesi için sözleşmede hüküm bulunması şartını aramaktadır. Ayrıca; TTK m. 255 hükmü kafa karıştırmaya müsaittir çünkü ortaklıktan çıkarma yapılması en temelde bir sözleşme değişikliğidir. TTK m. 226/II; "Şirket sözleşmesinin her ne şekilde olursa olsun deģ̆̈ştirilmesine ilişkin kararlar oybirliğ̈iyle, diğger kararlar ise, kanunda veya şirket sözleşmesinde aksine hüküm yoksa, ortaklarm çoğunluğunun oylarıyla verilir." ifadeleri ile kollektif şirketlerde sözleşme değişikliği bakımından tüm ortakların oybirliği gerektiğini açı şekilde ifade etmektedir. TTK m. 255'in gerekçesinde de; "Şirket sözleşmesinde böyle bir düzenleme bulunmasa bile şirket mezkûr ortağı şirketten çıkarabilir. Düzenleme çıkarma kararının hangi nisapla alınması gerektiği hususunda yapılabilir. Karar, kural olarak oybirliği ile alınmalıdır; ..." ifadelerine yer verilmiştir. Çıkarılacak ortağın bu konuda karara katılmayacağı ise açıktır. Haklı sebebin vuku bulması TTK m. 245 uyarınca sona erme sebebidir. Bu sona erme sebebinin çıkarma sebebi de olabilmesi için sözleşme hükmü gereklidir; sözleşme hükmü yok ise sözleşme değiştirilmelidir; sözleşme ise oybirliği ile değiştirilebilmektedir ve "diğer ortakların tümü" bu değişiklik için yeterli değildir. $\mathrm{Bu}$ açıdan bakıldığında bu hüküm hem şahıs şirketlerinin temel ilkeleri ile hem de açık şekilde sözleşmede hüküm bulunması gerektiğini belirten TBK m. 633 hükmü ile çelişmektedir ve bu nedenle adi ortaklıklara doğrudan uygulanması kanaatimizce mümkün değildir. Alman ve İsviçre hukuklarındaki kollektif şirketlere ilişkin aynı konudaki düzenlemelerde kalan ortakların dava açması gerektiği görülmektedir (HGB $\$ 140$ ve OR $\$$ 577). Bizce de kendi içerisinde mantıklı ve uygun olan yöntem budur. Adi ortaklıklar açısından TBK m. 633 bu konuda kendi içerisinde bütünlük arz etmektedir çünkü "sözleşmede ortaklığın diğer ortaklarla devam edeceğine

TÜRKMEN, bir ortağın hatalı davranışı yüzünden adi ortaklığı tasfiyeye sürüklememek gerektiğini; ayrıca ortaklara sadece fesih hakkının verilmesinin şahsında haklı sebebi doğuran ortağı bir nevi ödüllendirmek olduğunu dile getirmektedir (TÜRKMEN, s.93). 
ilişskin bir hükü̈m varsa... diğger ortaklar tarafindan yazılı olarak yapılacak bir bildirimle ortaklıktan çıkarılabilir” şeklindedir. TBK m. 633 hükmünde kalan ortaklar tarafından çıkarma yapılabilmesi sözleşmede hüküm bulunması şartına bağlanmış iken TTK m. 255/I hükmünün doğrudan uygulanması bizce mümkün değildir çünkü adi ortaklıklar açısından kanun koyucunun iradesi diğer ortaklar tarafından çıkarma yapılabilmesi için sözleşme hükmü bulunması gerektiği yönündedir. TTK m. 255/I'de yer verilen usûlün benimsenmesi TBK m. 633'ün göz ardı edilmesi anlamına gelecektir. Sözleşmede hüküm bulunmuyor ve ortakların kararı ile çıarma yapılamıyor ise eldeki seçenek mahkeme kararı olmalıdır ve "Birinci fikra uyarınca çıkarma kararı alınamadiğı takdirde, her ortak, şirket merkezinin bulunduğu yerdeki asliye ticaret mabkemesinden söz konusu ortăğn şirketten çıkarılmasın ve ayrlma payının belirlenmesini isteyebilir" ifadelerini haiz TTK m. 255'in üçüncü fikrası gündeme gelmektedir. Bizce; TTK m. 255/ III hükmünün de adi ortaklıklar bakımından uygulanması güç olacaktır. Bu fikra da kendi içerisinde çelişkiler barındırmaktadır. TTK m. 255/III fikrası tek bir ortağa ortaklıktan çıkarma davası açma hakkını tanımaktadır. Hükmün gerekçesi; "6762 sayıl Kanun, 197 nci maddesinin birinci fikrası uyarınca çıkarma kararı alınamaması veya buna teşebbüs edilmemesi hâlinde her bir ortağın mahkemede çıkarma davası açıp açamayacağı hususunda suskundur. Ü̧̧̈̈ncü fikra bu hakkt, yani, actio pro socioyu Yargitay kararları ile uyum içinde ve açıkça düzenlemiştir." şeklindedir. Gerekçeden anlaşıldığı üzere; ortaklıktan çıkarma davasının "actio pro socio" olduğu düşüncesi dayanak alınarak bu yönde bir hüküm getirilmiştir. Actio pro socio, Alman-İsviçre hukuklarında "sosyal taleplef" (Sozialenansprüche) olarak adlandırılan, bir ortağın başka bir ortağa karşı ortaklık ilişkisinden doğan talepleri arasında yer almaktadır. ${ }^{[17]}$ "Sosyal talepler"; katılım payı borcunun ifası dışında yönetim ve sadakat yükümlülüğüne aykırılık sonucunda oluşan talepleri de içermektedir. Bu bilgiler sşığında actio pro socio'nun ortaklık ilişkisinden doğan haklara/alacaklara ilişkin olduğu ve temelde bir ifa/eda davası olduğu görülmektedir. Ortaklıktan çıkarma kurumunda ise ortaklık ilişkisinde değişiklik meydana gelmesi istenmektedir ayrıca sözleşme ilişkisinden kaynaklanan bir alacak, talep vb. söz konusu değildir. Kanun koyucunun ortaklıktan çıkarma kurumunu actio pro socio olarak nitelemesi kanaatimizce hatalıdır. Bu nedenlerle TTK m. 255/III, ortaklıktan çıkarma kurumunun doğası ile çelişmektedir ve bu fikranın uygulanması da kanaatimizce güçtür. Son olarak; TTK m. 255 hükmünün gerekçesine bakmak gerekir. F1kranın gerekçesi: "6762 sayılı Kanunun 197 nci maddesinin birinci fikrasinda "mukavelede büküm bulunduğu takdirde"

[17] FÖRTSER, s.50-51. 
ibaresi iki şekilde yorumlanmaya müsaittir. Bir yoruma göre, şirket sözleşmesinde hüküm bulunduğu takdirde, diğer ortaklar, kişiliğinde hakl sebep doğan ortă̆ı bir kararla şirketten çıkarabilir. İkinci yorum uyarınca, diğer ortakların şahsında haklı sebep doğan ortağı şirketten çıkarma hakkı doğaldır. Bu yetkinin doğallı̆̆ı kollektif şirketin şahıs şirketi niteliğinden kaynaklanır. Onun için, söz konusu hakkın şirket sözleşmesinde bulunmast şart değildir. Şirket sözleşmesinde böyle bir düzenleme bulunmasa bile şirket mezkûr ortăğ şirketten çıkarabilir. Düzenleme çıkarma kararının hangi nisapla alınması gerektiği hususunda yapılabilir. Karar, kural olarak oybirliği ile alınmalıdır; ancak şirket sözleşmesinde hüküm varsa çoğunlukla da alınabilir. Yargitay, haklı olarak ikinci yorumu benimsemiştir. Tasar, birinci fikrayı bu yoruma uygun olarak düzenlemiştir. "şeklindedir. Gerekçe; adi ortaklıkların da dâhil olduğu şahıs şirketlerinde haklı sebeple çıkarmanın doğal, kendiliğinden bulunan bir kurum olduğunu tasdik etmektedir. Bu açıklamalar 1şı̆̆gnda; TTK m. 255 hükmünü, haklı sebeple ortağın çıkarılması konusunda destekleyici ama kendi içerisindeki çelişkiler nedeniyle doğrudan uygulanamayacak bir hüküm olarak ele alıyoruz. TTK m. 255'in yanında başka bir dayanağa daha ihtiyaç olduğunu düşünüyoruz. ${ }^{[18]}$

\section{3- İsviçre Hukukunda Durum}

Bu noktada konumuz ile ilgili İsviçre hukukundaki görüşler de ele alınmalıdır. İsviçre Federal Mahkemesi, adi ortaklıklarda çıkarma konusunda kanun koyucunun bilinçli olarak düzenleme yapmadığına ve İsviçre Borçlar Kanunu (OR) $\$ 577^{[19]}$ (kollektif şirketlerde haklı sebeple ve mahkeme kararı ile ortaklıktan çıkarma) hükmünün adi ortaklıklarda kıyas yoluyla uygulanamayacağına hükmetmiştir. ${ }^{[20]}$ OR $\$ 577$, kollektif şirketlerde söz-

[18] Bizce; TTK m. 255'in kafa karıştırmaya müsait ve çelişkili düzenlemesinin değiştirilmesi gerekmektedir. HGB $\$ 140$ veya OR $\$ 577$ benzeri bir hükmün getirilmesi ile bu kurum tekrar işlerlik kazanabilecektir.

[19] OR $\$$ 577: “Wenn die Auflösung der Gesellschaft aus wichtigen Gründen verlangt werden könnte und diese vorwiegend in der Person eines oder mehrerer Gesellschafter liegen, so kann der Richter auf deren Ausschliessung und auf Ausrichtung ihrer Anteile am Gesellschaftsvermögen erkennen, sofern alle übrigen Gesellschafter es beantragen." Hükmün tercümesi: "Kalan ortaklarm talep etmesi durumunda hâkim; ortaklı̆ğn haklı sebeple feshinin istenebildiği ve bu sebebin bir veya daha fazla ortağın şahsindan doğduğu durumlarda bu ortağın çıkarılmasına ve bu ortağın ortaklıktaki payının ödenmesine karar verebilir."

[20] BGE 94 II 119, 120 f. (http://relevancy.bger.ch/php/clir/httn/index.php7highlight docid=atf\%3A\%2F\%2F94-II-119\%3 Ade\&lang=de\&type=show document)

CHRİT, B. (2015). Personengesellschaftsrecht (Art. 530-619 OR)- Art. 545. Herausgeber: Schütz, J.G.. Bern. Stampfli Verlag AG, s.153. 
leşme hükmü bulunmasına gerek olmaksızın doğrudan dava yolu ile haklı sebep yaratan ortağın çıkarılması seçeneğini tanımaktadır. Sürekli borç ilişkilerinde tarafların, çekilmez hâle gelen sözleşme bağını çözme hakkı bulunmaktadır. Kişi ortaklıklarında bu durumda ilk bakışta fesih gündeme gelmektedir. Feshin alternatifi olarak da tezahür edebilen ortaklıktan çıkarma kurumunda ayrıca ortaklığı/işletmeyi koruma amacı bulunsa da temelde iki kurum da zedelenen ortaklık ilişkisini değiştirme imkânını sağlamaktadır. ${ }^{[21]}$ BERGSMA, bu açıdan yaklaşarak "a maiore ad minus" kuralı yani "büyüğe uygulananın küçüğe de uygulanacă̆ı"\{22] ilkesi gereği belirli bir ortağın çıkarılmasına ilişkin dava hakkı bulunduğunu ifade etmektedir. ${ }^{[23]}$ JUNG, İsviçre Federal Mahkemesi'nin belirtilen kararını eleştirerek, adi ortaklıklar ile ticaret/şahıs şirketleri arasında farklı değerlendirme yapmak için bir gerekçe bulunmadığını ve OR \$ 577’nin adi ortaklıklar

İsviçre Federal Mahkemesi'nin kararı ile aynı yönde doktrin görüşleri de bulunmaktadır (FRAEFEL, J. (1930). Die Auflösung der Gesellschaft aus wichtigem Grund. Diss. Zürich, s.107 vd.; BOLLMANN, H. (1971). Das Ausscheiden aus Personengesellschaften. Zürich. Schultess Polygraphischer Verlag AG, s.24-25. Bu görüş aynı zamanda ortaklığa devam etmek isteyen ortakların şekle tâbi olmaksızın ve haklı sebebi yaratan ortağı almaksızın yeniden ortaklık kurabileceklerini de dile getirmektedir).

BOLLMANN, kanunun adi ortaklıklar açısından haklı sebeple çıkma-çıkarmaya yer vermediğini, hâkimin haklı sebeple çıkarma yapabileceğini destekleyen bir düzenleme bulunmadığını dile getirerek adi ortaklıkta haklı sebeple çıkarmanın hâkimin dahli olmaksızın, devam hükmü sayesinde gerçekleşebileceğini ileri sürmektedir (BOLLMANN, s.49).

[21] İsviçre doktrininde; ortaklıktan çıkarmanın her zaman ortaklığı sona erdirmeye alternatif teşkil ettiği görüşü de kabul görmektedir. Sözleşmede ortaklığı sona erdirmek için öngörülen sebebin aynı zamanda ortaklıktan çıkarma için de kullanılabileceği ve sözleşmesel sona erdirme hakkı ile ortaklıktan çıkarma hakkının aynı sınırlara tâbi olduğunu belirtmektedir. Ancak bu görüş; sözleşmede "devam hükmü” bulunduğu nazara alınarak dile getirilmiştir (HANDSCHIN, L. (2014). "Die Auflösung der einfachen Gesellschaft". Gesellschafts- und Kapitalmarktrecht in Deutschland, Österreich und der Schweiz 2014. Seite: 215-254. Tübingen. Mohr Siebeck Verlag, s.247; HANDSCHIN, L./VONZUN, R. (2009). Kommentar zum schweizerischen Zivilrecht - Die Einfache Gesellschaft Art.530-551 OR. (4. Auflage). Zürich. Schultess Verlag, s.653; STAEHELIN, D./STRAUB, R.M. (2011). "Der Ausschluss aus einer Personengesellschaft ohne wichtige Gründe". Aktuelle Juristische Praxis 01/2011. Zürich/St.Gallen. Dike Verlag, s.27-30).

[22] Daha açık şekilde ifade etmek gerekirse; "Evleviyetle kuralı: Küçük için yasak olan büyük için de yasaktır, büyük için serbest olan kü̧̧ük için de serbesttir."

[23] BERGSMA, P. (1990). Aufösung, Ausschluss und Austritt aus wichtigem Grund bei den Personengesellschaften. Zürich. Peter Lang Verlag, s.100-101. 
açısından da uygulanması gerektiğini dile getirmektedir. Feshin ultima ratio olarak, ortaklıktan çıkarmanın ise daha yumuşak yaptırım (milderes Mittel) olarak düşünülmesi gerektiğini belirtmektedir. ${ }^{[24]} \mathrm{Bu}$ bağlamda; İsviçre doktrininde JUNG, BERGSMA ve HANDSCHIN/VONZUN ve SIEGWART ${ }^{1}{ }^{[25]}$ görüşleri, adi ortaklık sözleşmesinde hüküm bulunmasa dahi OR $\$ 577$ hükmünün kıyasen uygulanması ile haklı sebep oluşturan ortağın mahkeme kararı ile çıkarılabileceği sonucuna varmaktadır. ${ }^{[26]}$ OR'de adi ortaklıklarda çıkma-çıkarma kurumları düzenlenmemiştir. Bizde ise bu kurumlara Kanun'da yer verilmiş ancak "haklı sebeple çıarma"” konusunda hüküm öngörülmemiştir. Haklı sebeple çıkarma özelinde bakılacak olursa kanun boşluğu bulunması bakımından İsviçre hukuku ile benzerlik bulunduğu söylenebilecektir. İki ülkenin doktrininde de dile getirilen kollektif şirketlere ilişkin "haklı sebeple çıkarma" hükümlerinin kıyasen uygulanması ile boşluğun doldurulabileceği görüşleri de paralellik arz etmektedir. Buna karşılık; OR $\$ 577$ doğrudan mahkemeye başvuru ve inşaî karar ile çıkarma yapılmasını öngörmekte iken TTK m. 225 ilk aşamada ortakların kararı ile çıkarma yapılması şeklinde bir usûl getirmektedir.

\section{4- Alman Hukukunda Durum}

Adi ortaklıktan çıkarma hükmünün alındığı BGB ve Alman doktrinini de incelemek gerekmektedir. Mehaz BGB'nin 737.maddesinde, şahsında ortaklı̆̆ın feshi için haklı sebep gerçekleşen ortağın sözleşmede hüküm bulunması durumunda yine ortaklar tarafından çıkarılabileceği öngörülmektedir. ${ }^{[27]}$ Alman hukukunda kollektif şirketler açısından ise Alman Ticaret

[24] JUNG, P. (2016). "Scheiden tut weh? Ausscheiden und Abfindung von Personengesellschaftern”. Entwicklungen im Gesellschaftsrecht XI. Editör: Kunz, P./Jörg, F./Arter, O. Bern. Stampli Verlag, s.202-204.

[25] SIEGWART, A. (1938). Die Personengesellschaften, Kommentar zum Schweizerischen Zivilgesetzbuch. Band V/4. Zürich. Schultess \& Co.

[26] İsviçre doktrininde bu yöndeki görüşler genellikle OR $\$ 577$ hükmünün sadece ticarî işletme işleten adi ortaklıklar açısından uygulanabileceğini dile getirmektedir (HANDSCHIN/VONZUN, s.662 vd.; SIEGWART, s.206-207). TBK'nin ortaklıktan çıkarma kurumunu doğrudan düzenlemesi, bu düzenlemede bu şekilde ticarî işletme işleten adi ortaklık vb. gibi bir ayrıma gitmemesi nazara alınarak bu görüşlerin hukukumuzda uygulanamayacağını düşünüyoruz.

[27] Bu hükmün tamamlayıcı nitelikte olduğu kabul edilmektedir. Bu nedenle çıkarma sebeplerinin sözleşme ile sınırlanması, genişletilmesi, ortadan kaldırılması, değiştirilmesi ve yeniden tasarlaması mümkündür. Bu açıklama ortaklıktan çıkarma usûlü için de geçerlidir (SCHÖNE, T. (1992). Gesellschafterausschluss bei Personengesellschaften. Münster. Verlag Dr. Otto Schmidt KG Köln, s.22; HUECK, G./ 
Kanunu (HGB) $\$ 140$ ile dava yolu ile ortağın çıkarılabilmesi imkânı öngörülmüştür. HGB $\$ 140$, inşaî dava açllması ve sözleşmede devam hükmüne gerek olmaması bakımından BGB $\$ 737$ 'den farklılaşmaktadır. ${ }^{[28]}$ Ancak bu iki hükmün kendi kanun sistematikleri içerisinde değerlendirilmesi şarttır. BGB'de adi ortaklığın haklı sebeple feshi için de mahkeme kararına gerek yoktur. Buna karşlık Alman hukukunda kollektif şirketin haklı sebeple feshedilmesi için HGB $\$ 133$ gereği mahkemenin inşaî hükmü gerekmektedir. Diğer deyişle; adi ortaklıklarda hem çıkarma hem fesih için mahkeme kararına ihtiyaç yok iken kollektif şirketler açısından durum tam tersidir. Bu bağlamda BGB'nin adi ortaklıktan çıkarma açısından da dava öngörmemesi kendi içerisinde mantıklı olmaktadır. İsviçre/Türk hukuku ise adi ortaklığın feshi bakımından inşaî dava öngörmektedir ve BGB'den farklılaşmaktadır. Fesih ve ortaklıktan çıkarma kurumu arasında sıkı bir bağ bulunmaktadır. Ortaklıktan çıkarmanın, feshe alternatif teşkil eden yönüne vurgu yapmıştık. BGB'de adi ortaklığın feshinin mahkeme kararı ile yapılmıyor olması çıkarma usûlünün tayin edilmesine de etki etmektedir ve Türk hukuku ile Alman hukuku arasında bu konuda fark meydana getirmektedir. Bu nedenlerle; haklı sebeple çıkarma ve bunun ne şekilde yapılacağ konusunda Alman doktrini ve uygulamasının doğrudan tatbik edilemeyeceği düşüncesindeyiz.

WINDBICHLER, C. (2008). Gesellschaftrecht. (21. Auflage). München. Verlag C.H.Beck, s.81). Ortaklıktan çıkarma için gereken oybirliğinin, oy çokluğu olarak değiştirilmesi ve hatta çıkarma hakkının tek bir ortağa veya bir gruba tanınması da bu nedenlerle mümkündür (HUECK/WINDBICHLER, s.81 ve SCHÖNE, s.31).

[28] SCHÂFER, C./ULMER, P. (2017). Gesellschaft Bürgerlichen Rechts und Partnerschaftsgesellschaft. (7.Auflage). München. Verlag. C.H. Beck, Art.737, s.570.

BGB'nin adi ortaklıktan çıkarma için davaya gerek görmemesinin altında adi ortaklıkların ticarî amaç taşımayacağı ve bu nedenle güçlü bir hukukî güvenlik, hukukî korumaya gerek görmemesi yatmaktadır (SOERGEL, H./HADDING, W/KIESSLING, E. (2011). Soergel Kommentar zum Bürgerlichen Gesetzbuch Band 11/1. (13. Auflage). Stuttgart. W. Kohlhammer Verlag, s.298). Ülkemizde ise adi ortaklıkların ticarî amaçla kuruldukları görülmektedir. Ülkemizde şehirlerarası otoyol, havaalanı gibi çok büyük çapta işlerin adi ortaklık kurularak yapıldığı görülmektedir. Bu açıdan da mahkeme kararı ile çıkarma imkânını sakınmak hukukumuzda makul olmamaktadır. Bu açıdan bakıldığında; BGB hükmünün usûl açısından doğrudan iktisap edilmesinin sonuç bakımından farklar yaratmaya müsait olduğu göze çarpmaktadır. 


\section{5- Kanun Boşluğunun Nasıl Doldurulması Gerektiği İle İlgili Düşüncemiz}

Hemen yukarıda ortaya konulan farklar ve TBK'nın bu konuda iki farklı kanun sistemini birbirine geçirme teşebbüsü nazara alındığında ne Alman doktrini ne de İsviçre doktrini doğrudan takip edilebilecektir. Ortak şahsında gerçekleşen haklı sebep söz konusu olduğunda -ve sözleşmede "devam hükmü" bulunmadığında- dava yolu ile mi yoksa taraf iradesi ile mi inşâ̂ hakkın kullanılacağı konusunda farklı değerlendirme yapılması ve "kendi yolumuzun" bulunması gereklidir.

Adi ortaklıklarda bir ortak şahsında gerçekleşen haklı sebeple ortağın çıkarılması noktasındaki kanun boşluğunun nasıl doldurulacağına ilişkin doktrinimizde dile getirilen görüşleri yukarıda ele almıştık. Bizce bu boşluk, birbirini tamamlayan farklı gerekçeler göz önüne alınarak doldurulmalıdır. Bu noktada ilk aşamada ortaklıktan çıkarmanın, ortaklığın feshinden daha yumuşak, hafif bir yaptırım olması nazara alınmalıdır. Ortakların yaşadığı sorunlar, ilişkinin çekilmezliği bir ortağın çıkarılması ile giderilebilecek ise ortaklığı sona erdirerek, tasfiyeye sokmak ve emek ile oluşturulmuş birikimi, ortaklık faaliyetlerini sona erdirmek yoluna gidilmemelidir. Diğer deyişle; feshin yapılabildiği durumda evleviyet gereği ortaklıktan çıkarma yapılması ve ortaklığın devam edebilmesi mümkün olmalıdır. Ortak şahsında haklı sebep vuku bulduğunda sadece ortakl1ğın feshi yoluna gidilebileceği yönünde yorum yapılmamalıdır. Buna ek olarak; fesih son çare olarak ele alınan yaptırımdır. Feshin ultima ratio özelliğinin, ortaklıktan çıkarma kurumunun arka plândaki daha yumuşak yaptırım getirme amacı ile tamamlandığını söyleyebiliriz. İkinci olarak; yukarıda da belirttiğimiz gibi TTK m. 255 hükmü şahış şirketlerinde haklı sebeple ortaklıktan çıkarma yapılabileceğini gösteren bir hüküm olarak ele alınmalıdır. Bu bağlamda; bizce hem TBK m. 639/7 hem de TTK m. 225 birbirini tamamlar şekilde kanun boşluğunun doldurulmasında dayanak olabilecektir. Bunlara ek olarak; borçlar hukukumuzdaki ahde vefa ilkesi ve işlemin ayakta tutulması prensibi de ortaklığı sona erdirecek fesih yerine haklı sebep yaratan ortağın ortaklıktan çıkartılmasını desteklemektedir. Ortaklıktan çıkarma, en temelde emek ve çaba ile oluşturulmuş ortaklık değerlerinin korunması, işletmenin devamının sağlanması amacına matuf bir kurumdur. Adi ortaklıklarda haklı sebeplerle ortaklıktan çıkarma yapılabilmesi seçeneği reddedilir ise ortaklara sadece ortaklığın feshini talep etme ve sonradan haklı sebebi yaratan ortağı dişarıda bırakarak yeniden benzer bir ortaklık kurma yolu bırakılmaktadır. Bu yol ise ilk olarak ortaklığın feshi için dava açılması, ortaklığın tasfiye edilmesi, sonradan tekrar 
yeni bir ortaklık kurulması ve ortaklığın tekrar iş alması, işletme kurması vb.külfetler getirecektir. Mahkeme kararı ile çıkarma yapılabilmesi seçeneği bu açıdan da makul, faydalı bir yol olarak tezahür etmektedir. Ortakların ve piyasanın ekonomik menfaatlerinin ortaklığın faaliyete devam etmesi yönünde olacağı tahminden uzak değildir.

Adi ortaklıkta şahsında haklı sebep gerçekleşen ortağın ne şekilde çıkarılacağı, hangi usûlün takip edileceği incelenmelidir. Ortaklıktan çıkarma yapılması hukukî durumda değişiklik meydana getirdiği için inşaî etkiye sahiptir ve inşaî hak olarak ele alınmalıdır. Bu hakkın sözleşmede hüküm yok ise ortakların kararı/irade beyanı ile kullanılması ise -çıkarılacak ortağın katılmayacağı nazara alınarak- mümkün değildir. Bu nedenle geriye kalan seçenek dava yolu olmaktadır. ${ }^{[29]}$ Mahkeme, açılan davada hukukî yararın bulunduğu kanaatine varır ve talebi haklı görürse davayı kabul etmeli ve inşaî niteliği haiz bir karar vermelidir. ${ }^{[30]}$ Daha önce de belirttiğimiz gibi ortaklıktan çıkarma, feshe benzer ancak daha yumuşak bir yaptırım olarak ele alınmalıdır. Bizce; adi ortaklıktan haklı sebeple çıkarma açısından haklı sebeple feshe paralel değerlendirme yapılması ve adi ortaklıklarda bir ortağın haklı sebeple çıkarılması açısından TBK m. 639/7 hükmünden hareket edilmesi gerekir. Bu açıdan bakıldığında hakkın dava yolu ile kullanılması

[29] İnşai davalarda mahkeme; önüne gelen davada önce inşaî hakkın varlığını tespit etmekte sonrasında ise bu hakkın kullanılması için gereken şartların bulunup bulunmadığına bakmaktadır. Diğer deyişle; hakkın varlığının ve sonuçlarının mahkemece takdir edilmesi gerekmektedir. Adi ortaklığın feshi davası tipik örnek olarak verilmektedir (DEMİRBAŞ, H. (2006). Yenilik Doğuran Haklar. Yayımlanmamış Yüksek Lisans Tezi. İstanbul Üniversitesi Sosyal Bilimler Enstitüsü, İstanbul, s.92). Yenilik doğuran davalar ile yenilik doğuran haklar arasındaki ilişki bu davanın arkasında yenilik doğuran hak bulunmasına gerek olup olmadığı noktasında tartışmalıdır. Medeni hukuk doktrininde hakim görüş; yenilik doğuran davanın, özel hukuktan kaynaklanan (yenilik doğuran) bir hakka dayandığıdır. Burada hakkın kullanım şekli açısından fark bulunmaktadır (BUZ, V. (2005). Medeni Hukukta Yenilik Doğuran Haklar. Ankara. Yetkin Yayınları, s.187-188).

[30] İnşai davaların sınırlı sayıda olduğuna ilişkin aksi yönde görüş için; ALTHAMMER, C. (2012). Streitgegenstand und Interesse. Tübingen. Mohr Siebeck Verlag, s.594 vd.; SCHELLHAMMER, K. (2004). Zivilprozess- Gesetz-Praxis-Falle. (U.Auflage). Heidelberg. C.F.Müller Verlag, s.98; BUZ, s.186-187.

$\mathrm{Bu}$ konuda; sözleşme ile inşai dava yaratılamayacağı ancak inşai davaların uygulama alanının kıyas yolu ile genişletilebileceği belirtilmektedir. İsviçre doktrinindeki OR $\$ 577$ 'nin kıyasen uygulanacağını belirten görüşler de bunu savunmaktadır (TÜRKMEN, E. (2020). Adi Ortaklıkta Çıkma ve Çıkarılma. Ankara. Seçkin Yayınları, s.196-197 (TÜRKMEN, ÇIKMA-ÇIKARILMA)). Bizce de bu görüşe itibar edilmesi doğrudur. 
açısından da ortaklığın feshedilmesine benzer bir usûl takip edilmelidir. Mahkeme bu durumda öncelikle haklı sebebe ilişkin ilke ve koşullara bakmalı ve somut duruma göre değerlendirme yapmalıdır. Farklı olan ise adi ortaklığın feshine değil, şahsında haklı sebep gerçekleşen ortağın çıkarılmasına karar verilecek olmasıdır. Bu teorik açıklamanın ve görüşümüzün mevzuatımızın elverişliliği bakımından da ele alınması şarttır. Haklı sebepler TBK m. 633'de belirtilmediği için çıkarmanın ortakların alacağı karar ve yapacakları bildirim ile meydana gelmesi mümkün değildir. TTK $\mathrm{m}$. 255/I hükmünde zikredilen kalan ortakların kararı ile çıkarma yapılması; gerek kendi içindeki çelişkiler gerekse de TBK m. 633'de yer verilen "sözleşmede ortakliğın diğer ortaklarla devam edeceğine ilişkin bir hüküm varsa" ifadesi yani tüm ortakların mutabık olması gerektiği vurgusu nedeniyle uygulanamayacaktır. Mahkemenin inşaî kararı ile ortaklıktan çıkarma yapilması; kanaatimizce TTK m. 255/III, TBK m. 639/7 ve Alman-İsviçre mevzuatındaki kollektif şirketten çıkarma hükümleri ile uyumlu olan yoldur. Bir ortağa bağlanabilen sebeple fesih mahkemeden talep edilebilirken aynı durumda bu ortağın çıkarılması da ancak mahkemenin kararı ile söz konusu olabilmelidir. Adi ortaklıklarda sözleşme hükmü bulunmasa dahi haklı sebeplere dayalı olarak doğrudan mahkeme kararı ile ortaklıktan çıkarma yapilabilmesine -TTK m. $255^{\prime}$ in de yorumu ve desteği ile- TBK m. 639/7 maddesinin yani mahkeme kararı ile haklı sebebe dayalı feshedilebileceği hükmünün evleviyetle uygulanabileceği düşüncesinden hareketle varıyoruz. TBK m. 633'de zikredilen devam hükmü inşaî hakkın ortaklar tarafından kullanılması ile davasız şekilde çıkarma yapmayı sağlamaktadır ve süreci kolaylaştıran bir anlaşma olarak düşünülmelidir. Eğer ortaklar, sözleşme ile haklı sebeple çıkarma hükmünü getirmişler ise mahkemenin inşaî kararını beklemeye gerek olmaksızın kısa sürede ortağı kendi alacakları karar ile çıkarabileceklerdir. Sözleşmede hüküm bulunmadığında ise inşâ̂ hakkın mahkemeye başvuru yaparak ve inşaî hüküm alınarak kullanılması seçeneği kalacaktır. ${ }^{[31]} \mathrm{Bu}$ açıklamalar doğrultusunda mevzuatı-

[31] Adi ortaklıklarda haklı sebeple ortağın çıkarılmasının mahiyetine de değinmek gerekir. Ortaklıktan çıkarma, mevcut durumun değiştirilmesini sağlayan bir hak olarak ele alınmalıdır. Mevcut durumu değiştirdiği için inşaî bir etkisi olduğu görülmektedir. Bu inşaî etkiyi meydana getirmek ise kural olarak taraflann/ortaklann anlaşmasına bağlıdır. Çıkarılacak ortağın bu anlaşmaya katılmayacağı düşünüldügünde ise geriye mahkemeye başvurma seçeneği kalmaktadır. Mahkeme bu noktada talep sonucunu inceleyerek, hukukî yarar olup olmadığına bakmalıdır. Bu bölümde yaptığımız açıklamalar ise bu kurumun işletilmesinin hukukî yararı olduğunu işaret etmektedir.

Bu düşünce; iki atıf yukarıda yer verdiğimiz yenilik doğuran davanın yenilik doğuran haktan doğduğu görüşü ile de desteklenmektedir. 
mızın, haklı sebeplerle adi ortaklıklarda ortağın çıkarılması ve ortaklığın devamına yönelik karar verilmesi için hâkime başvurulmasına elverişli olduğunu düşünüyoruz.

Bu görüşümüz ile ilgili ele alınması gereken bir diğer nokta ise mahkemeye başvurunun kim tarafından yapılacağıdır. Örnek olarak; beş kişilik bir adi ortaklıkta iki ortağın arasının bozulması söz konusu olabilir. Bu ortaklardan birisi, arasının bozuk olduğu ortağı çıkarmak için mahkemeye başvuru yapabilir mi? Kalan ortaklar diğer ortağın ortaklıkta devam etmesini istiyor olabilirler. TTK $\mathrm{m}$. 255/III fikrası tek bir ortağa ortaklıktan çıkarma davası açma hakkını tanımaktadır. Bu fikraya ilişkin eleştirimiz yukarıda detaylı şekilde dile getirilmiştir. Çok kısaca tekrarlamak gerekirse; kanun koyucumuzun ortaklıktan çıkarma davasını bizce hatalı olarak actiopro socio olarak nitelemesi nedeniyle TTK m. 255/III, ortaklıktan çıkarma kurumunun doğası ile çelişmektedir. OR'deki kollektif şirketlerde haklı sebeple çıkarma hükmü; ortağın şahsında haklı sebep vuku bulduğunda bu ortağın çıkarılması için kalan ortakların mahkemeye başvurması gerektiğini ("sofern alle übrigen Gesellschafter es beantragen") belirtmektedir. HGB de kollektif şirket açısından aynı yönde, kalan ortakların birlikte dava açması şeklinde bir hüküm öngörmüştür. ${ }^{[32]}$ TTK, hatalı bir gerekçe ile hatalı bir hüküm getirmiştir. Kanaatimizce; bu hükmün, Alman-İsviçre hukuklarında olduğu gibi ortaklıktan çıkarma davasının kalan ortaklar tarafından birlikte açılması şeklinde değiştirilmesi gerekmektedir. Bizce; mahkemeye başvurunun kalan ortakların tamamı tarafından yapılması gerekli ve mümkündür. ${ }^{[33]} \mathrm{Bu}$ sonuca hukukumuzda da ulaşmamızı sağlayan farklı ilke ve hükümler söz konusudur. Öncelikle; ortaklıktan çıkarma kural olarak kalan ortakların birlikte kullanabileceği bir hak olarak tezahür etmektedir. Haklı sebeple fesih talebinden bu noktada farklılaşmaktadır. Bu kurumun doğası; sadece iki ortak arasındaki sorunları çözmek amacına matuf değildir. İkinci olarak; adi ortaklık ortaklarının birlikte hareket etmesi, davada dava arkadaşı olması gerekmektedir. Ortaklıktan çıkarma kurumunun mahiyeti ve çıkarılacak ortağın davalı olacağı göz önüne alınarak burada kalan ortakların birlikte davacı olması gerektiği sonucuna varılmaktadır. Son olarak; TBK m. 633 hükmünde açık şekilde belirtilmese de kalan ortakların her hâlükarda çıkarmaya yönelik bir karar alması gerekmektedir. Sözleşmede devam anlaşması bulunmadığında da kanaatimizce yine karar alınması gerekir ve bu karar ortağın çıkarılması için mahkemeye

[32] HGB $₫ 140$; “...sofern die übrigen Gesellschafter dies beantragen...”

[33] TTK m. 225/III hükmünün kıyasen uygulanması ile adi ortaklıklarda ortaklıktan çıkarma davasına işlerlik kazandırılmasına dair görüş TÜRKMEN, ÇIKMA-ÇIKARILMA, s. 198. 
başvuru yapma yönünde olmalıdır. Bu durumda; davacı ortakların, çıkarılması istenen davalı ortak sebebiyle sözleşme ilişkine devam edemeyecek olması gerekmektedir. Bu davanın açılması ile birlikte kalan ortaklar fesihten farklı olarak sözleşme ilişkisine tutunmak, devam etmek niyetlerini dile getirmiş olmaktadır. ${ }^{[34]}$ Sözleşmede ortaklıktan çıkarmaya ilişkin bir düzenleme yok ancak ortaklık kararı çoğunluğu ile ilgili farklı bir düzenleme var ise yani oybirliği ilkesinden feragat edilmiş ise durumun ne olacağ $1 \mathrm{da}$ düşünülmelidir. İsviçre doktrininde çıkarma davasının tek ortak veya belirli çoğunluk tarafından açllabileceğine ilişkin sözleşme hükümleri geçerli addedilmektedir. ${ }^{[35]}$ Bizce; sözleşme ile ortaklık kararı alınması açısından farklı bir çoğunluk öngörülmüş ise önce sözleşmenin değiştirilmesi ve ortaklıktan çıkarma hakkının getirilmesi ve sonrasında bu hükme dayanarak ortakların kararı ile çıkarma yapılması mümkündür.

Sonuç olarak; kanaatimize göre adi ortaklık sözleşmesinde ortaklıktan çıkarma yapılabileceği ve ortaklığın devam edeceği kararlaştıılmış olmasa bile bir ortak şahsında haklı sebep vuku bulduğunda TTK $\mathrm{m}$. 255 ve TBK m. 639/7 hükümleri birlikte dayanak alınarak mahkemeden ortağın çıkartılması talep edilebilecektir. Bu durumda kalan ortakların tamamının birlikte davacı olması gerekecektir. Bizce; mevzuatımız bu sonuca varmaya engel teşkil etmemektedir. Bununla birlikte; -TTK m. 255 gerekçesinde belirtildiği gibi- şahışş şrketlerinin doğasında bulunan bu kurumun daha açık ve net şekilde düzenlenmesi; hakkın yorum, kıyasen uygulama yolu ile değil doğrudan açık kanun hükümleri ile verilmesi bir gereklilik olarak tezahür etmektedir.

Adi ortaklık sözleşmesi hükümlerine;

"Bir veya birden fazla ortağın şahsindan kaynaklanan haklı sebeplerle ortakliğın feshinin istenebileceği durumlarda kalan ortaklar mahkemeye başvurarak bu ortă̆ın çıkarılmasın ve ortaklığın kalan ortaklarla devam etmesini talep edebilirler. " benzeri bir hüküm getirilmesi yerinde olacaktır. ${ }^{[36]}$

Türk Ticaret Kanunu'nun 255.maddesi yerine ise HGB $₫ 140$ doğrudan iktibas edilebilir. Bu sayede; sözleşmede çıkarma ve ortaklığın de-

[34] BERGSMA, s.94-95. Davalı, birden fazla ortak da olabilir.

[35] BERGSMA, s.102.

Alman doktrininde ortaklıktan çıkarmanın da dahil edilebileceği "temel işlemler" açısından her zaman oybirliği gerekeceği yönünde görüş de bulunmaktadır.

[36] Doktrinde TÜRKMEN'de yasa değişikliği önerisi getirmektedir. Yazar' 'n değişiklik önerisi TTK m. 255 ile paraleldir. (TÜRKMEN, Makale, s,94-95.) 
vamına ilişkin hüküm aranmaksızın, kalan ortakların birlikte başvurusu ile mahkeme tarafından çıkarma yapılabilecek ve TTK m. $255^{\prime}$ in çelişkili yapısı düzelebilecektir.

Son olarak adi ortaklık sözleşmesinde hüküm bulunmamasına rağmen ortak özelinde haklı sebeple fesih nedeninin gerçekleşmesi ve ortakların bu olgunun ortaya çıkmasını takiben alacakları karar ile bir ortağın ayrılmasının mümkün olduğu belirtilmektedir. ${ }^{[37]}$ Burada çıkarılma değil çıkma olduğu gözden kaçmamalıdır. Çıkacak ortağın da karara katılması ve oybirliği ile kararın alınması gerekmektedir. Çıkarılması istenen ortağın da katılımı varsa bu durumda çıkarmadan bahsetmek kanaatimizce söz konusu olmayacaktır çünkü çıkarılma temelde o ortağın isteği hilafına sonuç doğurmaktadır.

\section{KAYNAKÇA}

AKKANAT, H. (2004). "Adi Ortaklıkta Haklı Sebeple İhraç Mümkün müdür?”, İÜHFM, C. LXII, S.1-2, İstanbul.

AKTAŞ, S. (2010). "Pozitif Hukukta Boşluk Kavramı”. Erzincan Üniversitesi Hukuk Fakültesi Dergisi C. XIV, S. 1-2. Erzincan (http://hukukdergi .erzincan.edu.tr/wp-content/uploads/2015/10/2010-XIV 1-1.pdf. Erişim Tarihi: 20.02.2021).

AKYAZAN, S. (1979). Kollektif, Komandit ve Adi Ortakliklardan Oluşan Şahıs Şirketlerinde, Ortaklığın Fesih ve İnfisahı ve Ortaklıktan Çıkarma. Ankara Barosu Dergisi Y11:1979 Sayı:5. Ankara.

ALTHAMMER, C. (2012). Streitgegenstand und Interesse. Tübingen. Mohr Siebeck Verlag. BADAK AYBAR, Z. (2013). "6098 saynlı Türk Borçlar Kanunu'na Göre Adi Ortaklık Sözleşmesindeki Yenilikler ve Değişiklikler". İstanbul Ticaret Üniverstesi Sosyal Bilimler Dergisi. Y11:12 Sayı:24 Güz 2013/2. İstanbul.

BERGER, B. (2018). Allegemeines Schuldrecht. (3. Auflage). Bern. Stampfli Verlag. BERGSMA, P. (1990). Auflösung, Ausschluss und Austritt aus wichtigem Grund bei den Personengesellschaften. Zürich. Peter Lang Verlag.

BİLGE, N. (2007). Hukuk Başlangıcı Hukukun Temel Kavram ve Kurumları. (22.Baskı). Ankara. Turhan Kitabevi.

[37] HANDSCHIN/VONZUN, s.663-664. 
BUZ, V. (2005). Medeni Hukukta Yenilik Doğuran Haklar. Ankara. Yetkin Yayınları.

BOllmanN, H. (1971). Das Ausscheiden aus Personengesellschaften. Zürich. Schultess Polygraphischer Verlag.

CHRİST, B. (2015). Personengesellschaftsrecht (Art. 530-619 OR)- Art. 545. Herausgeber: Schütz, J.G.. Bern. Stampfli Verlag AG.

ÇAMOĞLU, E. (1976). Kollektif Ortaklıkta Haklı Sebep Kavramı ve Ortağın Haklı Sebeple Çıkarılması. İstanbul. Fakülteler Matbaası.

ÇELIK, A. (2017). Anonim Şirketlerde Ortaklıktan Çıkarılma. (4.Baskı). Ankara. Seçkin Yayınları.

ÇELİKBOYA, K. (2015). "Adi Ortaklıktan Çıkma ve Çıkarmanın Koşulları”. Galatasaray Üniversitesi Hukuk Fakültesi Dergisi. Sayı:2015/2. İstanbul. Beta Yayınları.

DEMİRBAŞ, H. (2006). Yenilik Doğuran Haklar. Yayımlanmamış Yüksek Lisans Tezi. İstanbul Üniversitesi Sosyal Bilimler Enstitüsü, İstanbul.

DOMANIÇ, H. (1968). Adi, Kollektifve Komandit Şirketler. (2.Baskı). İstanbul. Fakülteler Matbaası.

EDİS, S. (1993). Medenî Hukuka Giriş ve Başlangı̧ Hükümleri. (4.Baskı). Ankara. Dokuz Eylül Üniverstesi Hukuk Fakültesi Yayınları.

FORTMOSER, P./VOGT. H. (2008). Einführung in das Recht. (4. Auflage). Bern. Stampfli Verlag.

FRAEFEL, J. (1930). Die Auflösung der Gesellschaft aus wichtigem Grund. Diss. Zürich.

GÖZLER, K. (2011). Hukuka Giriş. (8.Bask1). Bursa. Ekin Basın Yayın Dağıtım.

HANDSCHIN, L. (2014). "Die Aufösung der einfachen Gesellschaft". Gesellschafts- und Kapitalmarktrecht in Deutschland, Österreich und der Schweiz 2014. Seite: 215-254. Tübingen. Mohr Siebeck Verlag.

HANDSCHIN, L./VONZUN, R. (2009). Kommentar zum schweizerischen Zivilrecht - Die Einfache Gesellschaft Art.530-551 OR. (4. Auflage). Zürich. Schultess Verlag. 
HIZIR, S. (2011). “6098 Sayılı (Yeni) Borçlar Kanunu’nun 633’üncü Maddesine Göre Adi Şirketten Çıkmanın ve Çıkarılmanın Geel Şartları ve Usulü”. Sarper Süzek’e Armağan. İstanbul. Beta Yayınları.

HUECK, G./WINDDBİCHLER, C. (2008). Gesellschaftrecht. (21. Auflage). München. Verlag C.H.Beck.

JUNG, P. (2016). "Scheiden tut weh? Ausscheiden und Abfindung von Personengesellschaftern". Entwicklungen im Gesellschaftsrecht XI. Editör: Kunz, P./Jörg, F./Arter, O. Bern. Stampfli Verlag.

KARAHAN, S ./AKIN, M.Y. (2013). Şirketler Hukuku. (2.Baskı). Konya. Mimoza Yayınları.

KARAYALÇIN, Y. (1972). Ticaret Hukuku II. Şirketler Hukuku. (2.Baskı). Ankara. Sevinç Matbaası.

SCHÂFER, C./ULMER, P. (2017). Gesellschaft Bürgerlichen Rechts und Partnerschaftsgesellschaft. (7.Auflage). München. Verlag. C.H. Beck.

SCHELLHAMMER, K. (2004). Zivilprozess-Gesetz-Praxis-Falle. (11. Auflage). Heidelberg. C.F.Müller Verlag.

SCHÖNE, T. (1992). Gesellschafterausschluss bei Personengesellschaften. Münster. Verlag Dr. Otto Schmidt KG Köln.

SIEGWART, A. (1938). Die Personengesellschaften, Kommentar zum Schweizerischen Zivilgesetzbuch. Band V/4. Zürich. Schultess \& Co.

SOERGEL, H./HADDİNG, W/KİESSLING, E. (2011). Soergel Kommentar zum Bürgerlichen Gesetzbuch Band 11/1. (13. Auflage). Stuttgart. W. Kohlhammer Verlag.

STAEHELIN, D./STRAUB, R.M. (2011). "Der Ausschluss aus einer Personengesellschaft ohne wichtige Gründe". Aktuelle Juristische Praxis 01/2011. Zürich/St.Gallen. Dike Verlag.

ŞENER, OH. (2015). Teorik ve Uygulamalı Ortakliklar Hukuku Ders Kitabı. (2.Baskı). Ankara. Seçkin Yayıncılık.

TÜRKMEN, E. (2018). "Adi Ortaklıkta Haklı Sebeple Çıkarma Bağlamında TBK 633 Hükmüne Eleştirel Bir Bakı̧̧”. Terazi Hukuk Dergisi Cilt: 13 Sayı:148. Ankara. Seçkin Yayınları.

TÜRKMEN, E. (2020). Adi Ortaklıkta Çıkma ve Çıkarlma. Ankara. Seçkin Yayınları, s.196-197 (TÜRKMEN, ÇIKMA-ÇIKARILMA). 